\title{
Extraction and Application of Natural Dyes from Brazilwood and Water guava leaves
}

\author{
Nita kusumawati* \\ dept. of Chemistry \\ Universitas Negeri Surabaya \\ Surabaya, Indonesia \\ nkusumawati82@yahoo.com
}

\author{
Samik \\ dept. of Chemistry \\ Universitas Negeri Surabaya \\ Surabaya, Indonesia \\ samik@unesa.ac.id
}

\author{
Supari Muslim \\ dept. of Electrical Engineering \\ Universitas Negeri Surabaya \\ Surabaya, Indonesia \\ suparimuslim@gmail.com
}

\begin{abstract}
The use of natural dyes for batik has some advantages because it produces a unique exotic color with exclusive imaging and is environmentally friendly due to the waste easily degraded. The purpose of this research was to obtain textile dye extract from brazilwood (Caesalpiniasappan $L$ ) and water guava (Syzygiumaqueum)leaves with various compotitions and fixer, i.e., alum, calcium carbonate and ferrous sulphate. The mordant used is alum and soda ash $\left(\mathrm{Na}_{2} \mathrm{CO}_{3}\right)$. The highest color intensity $(87.63 \%)$ was obtained from brazilwood/water guava leavesratio $50 / 50$ and ferrous sulphate fixer, while the lowest $(35.60 \%)$ from ratio $25 / 75$ and calcium carbonate fixer.
\end{abstract}

Keywords-Natural dyes, Caesalpiniasappan Syzygiumaqueum, fixer, color intensity

\section{INTRODUCTION}

Batik dyes can be grouped into two according to their origin, namely natural and synthetic dyes [1]. Although known for its bright color, synthetic dyes are toxic and cause significant environmental damage For this reason, the use of natural dyes needs to be optimized [2]. According to publication [3], a large amount of natural coloring is obtained from plant products, where plant tissues contain pigments which vary depending on their chemical structure.

Natural dyes have better biodegradability and generally have high compatibility with the environment. This dye also does not trigger skin allergies, non-carcinogenic, easily available and renewable [4-5]. Natural dyes can be grouped into several groups according to their chemical structure such as indigo, anthraquinone, $\alpha$-naphtoquinone, flavones, dihydropyran, anthocyanidin, and carotenoids [6]. Dyes molecules contain two chemical groups, namely chromophores and auxochromes [7].

Brazilwood (Caesalpiniasappan Linn) and water guava (Syzygiumaqueum) leaves are two types of natural dyes that can be used for batik dyeing [6]. Brazilwood contains tannin, brazilin, tannic acid, resin, resorcinin, saponin, and gallic acid. Brazilwood produces sharp and bright red pigments from Brazil [3];[8-9].

Water guava leaves can be used as batik dyes because they contain tannin compounds which give a reddish brown color [10]. Tannin is a group of polyphenols that are water soluble and form a deep red color with potassium ferricyanide and ammonia [11].
In natural dyeing, the formation of complex compounds between dyes and fabric fibers will occur during dyeing. To optimize this, the role of mordant compounds with more than one positive valence is needed, to help bind color to the fabric through the formation of chemical bridges [6]. Related to this, to maintain the intensity of the color obtained, a fixation procedure was applied. This procedure can reduce the reactivity of dyes with material from the surrounding environment through color locking. Thus, the color fastness obtained will be better [11]. Alum, ferrous sulfate, and lime are the three types of fixer compounds that can be used for this purpose.

To determine the potential use of brazilwood and water guava leaves dye extract for batik natural dyeing, the effect of various dye compositions and fixer types on the intensity and color fastness of cotton fibers was evaluated.

\section{MATERIAL AND METHODS}

\section{A. Material}

Brazilwood bark was purchased from a herbal drug store UD. Dwi Jaya (Surabaya, Indonesia), while water guava leaves are purchased from traditional markets (Surabaya, Indonesia). Before being applied to dyeing, the two materials must go through a drying process at $50{ }^{\circ} \mathrm{C}$ to get a moisture content below $10 \%$. Distilled water used as a solvent for the extraction of brazillin and curcumin was obtained from AMDK Universitas Negeri Surabaya (Surabaya, Indonesia). To minimize the presence of contaminants that have the potential to inhibit the reaction of cotton fibers with mordant, treatment is carried out using Turkish Red Oil (TRO) ( $\geq 70 \%)$ purchased from CV. Dunia Kimia (Surabaya, Indonesia). Alum or aluminum sulfate $\left[\mathrm{Al}_{2}\left(\mathrm{SO}_{4}\right)_{3} .18 \mathrm{H}_{2} \mathrm{O}\right] \quad(\geq 17 \%)$ purchased from PT. Brataco Chemistry (Surabaya, Indonesia) has a dual function, namely as a mordant together with soda ash $\left(\mathrm{Na}_{2} \mathrm{CO}_{3}\right)(\geq 48 \%)$ which is purchased from CV.Water (Surabaya, Indonesia) as well as one of the fixer compounds. While two other fixers are used, namely iron (II) sulfate $\left(\mathrm{FeSO}_{4} \cdot 7 \mathrm{H}_{2} \mathrm{O}\right)\left(\mathrm{d} 2.84 \mathrm{~g} / \mathrm{cm}^{3}\right)$ and calcium oxide $(\mathrm{CaO})$ $(\geq 90 \%)$ each purchased from PT. Nusa Indah Megah (Surabaya, Indonesia) and Mitra Water (Surabaya, Indonesia).

\section{B. Methods}

Washing. Washing is done to minimize contaminants in cotton fibers that have the potential to inhibit reactions, both with mordant or dyes. Increasing the intensity and color fastness at this stage is done by immersing $2.57 \mathrm{~g}$ of cotton 
fiber in $2 \mathrm{~g} / \mathrm{L} \mathrm{TRO}$ for $6 \mathrm{~h}$. To remove mordant residues that do not react with fiber, rinse with distilled water 3 times. This washing procedure ends with drying the fibers in the open air for $24 \mathrm{~h} \mathrm{[12].}$

Mordant. To increase the reactivity between cotton fibers with brazilin and tannin dyes, mordanting using alum and soda ash has been carried out. Mordant solution is made from $8 \mathrm{~g}$ of alum and $2 \mathrm{~g}$ of soda ash in $1 \mathrm{~L}$ of distilled water. To optimize the homogeneity of the solution, stirring was carried out using a magnetic stirrer for 5 minutes. The solution is then heated to $100^{\circ} \mathrm{C}$ and $2.57 \mathrm{~g}$ of cotton fiber is added to it. This immersion process is carried out for $1 \mathrm{~h}$. To optimize the reaction between cotton fiber and mordant, immersing is continued for $24 \mathrm{~h}$ without heating. To remove the remaining mordant in the fabric, the fiber is rinsed three times without being squeezed, dried and then ironed to get a uniform fiber orientation [12].

Dyeing. The dyeing procedure with brazilwood bark extract and water guava leaves is carried out by following the operational conditions as presented in Table 1 and the mixture composition as in Table 2 [12].

TABLE I. THEDYEINGPROCESS OPERATIONAL CONDITIONS

\begin{tabular}{lll}
\hline No & Operational Conditions & \\
\hline 1 & Material : liquor & $1 / 35(\mathrm{~g} / \mathrm{mL})$ \\
\hline 2 & Temperature & Ambient temperature \\
\hline 3 & Fiber weight & $0.85 \mathrm{~g}$ \\
\hline 4 & Dyeing time & $50 \mathrm{~min}$ \\
\hline
\end{tabular}

TABLE II. THE BLENDING COMPOSITIONS

\begin{tabular}{lllll}
\hline No & Type of Blending & $\begin{array}{l}\text { Extract Compositions } \\
(\boldsymbol{\%})\end{array}$ & Fixer \\
\cline { 3 - 4 } & & $\begin{array}{l}\text { Brazilwood } \\
\text { bark }\end{array}$ & $\begin{array}{l}\text { Water } \\
\text { guava } \\
\text { leaves }\end{array}$ & \\
\hline 1 & BWB/WGL-1a & 75 & 25 & $\begin{array}{l}\text { Ferrous } \\
\text { sulphate }\end{array}$ \\
\hline 2 & BWB/WGL-1b & 75 & 25 & Alum \\
\hline 3 & BWB/WGL-1c & 75 & 25 & Calcium oxide \\
\hline 4 & BWB/WGL-2a & 50 & 50 & Ferrous \\
& & & $501 p h a t e$ \\
\hline 5 & BWB/WGL-2b & 50 & 50 & Alum \\
\hline 6 & BWB/WGL-2c & 50 & 50 & Calcium oxide \\
\hline 7 & BWB/WGL-3a & 25 & 75 & $\begin{array}{l}\text { Ferrous } \\
\text { sulphate }\end{array}$ \\
\hline 8 & BWB/WGL-3b & 25 & 75 & Alum \\
\hline 9 & BWB/WGL-3c & 25 & 75 & Calcium oxide \\
\hline
\end{tabular}

Fixation. The color locking process in cotton fibers is carried out using three fixers, including iron(II)sulfate, alum and calcium oxide. This process will reduce the reactivity of dye compounds in the fabric fibers, thereby reducing the potential for color loss. Each fixer solution was prepared by dissolving $50 \mathrm{~g}$ of the fixer compound in $1 \mathrm{~L}$ of distilled water. The solution is then allowed to stand for $24 \mathrm{~h}$ to get a transparent part. Fixation were done by immersing $0.85 \mathrm{~g}$ of cotton fiber in $30 \mathrm{~mL}$ of the fixer solution for $10 \mathrm{~min}$. The fixation process is ended by rinsing the fiber using distilled water (three times, each by $100 \mathrm{~mL}$ ) and drying in the open air [12].

Characterization. To investigate the characteristics of the dye compounds contained in brazilwood bark and water guava leaves extracts, an analysis of wavelength region was carried out, using Pharmaspec UV-1700 UV-Visible Spectrophotometer. The maximum wavelength region $(\lambda \max )$ produced can provide information about the dominant dyeing compounds in the dye extract. Meanwhile, color intensity analysis of fabric samples is carried out to determine the changes that occur as a result of the washing process with varying times, the frequency of dyeing as well as the different fixer uses. Color intensity analysis was performed using the Shimadzu UV-2401-PC DiffuseReflectant Ultraviolet (DRUV) Spectrophotometer. In general, a higher color intensity will result in a lower percentage of reflectance in the DRUV result.

\section{RESULT AND DISCUSSIONS}

Washing. The purpose of the washing procedure is to minimize the presence of contaminants in cotton fibers, which can inhibit the reaction with mordant compounds. Contaminants, especially those that are positively charged, have the potential to play the same role as mordant. However, most of these contaminants only rely on physical interaction with fibers so that they are easily removed along with the washing process. This will automatically increase color fastness. In addition, the presence of specific chromophore and auxochrome groups in contaminants can influence the final result of dyeing. Figure 1. illustrates the mechanism of TRO action in releasing contaminants from fiber to water.
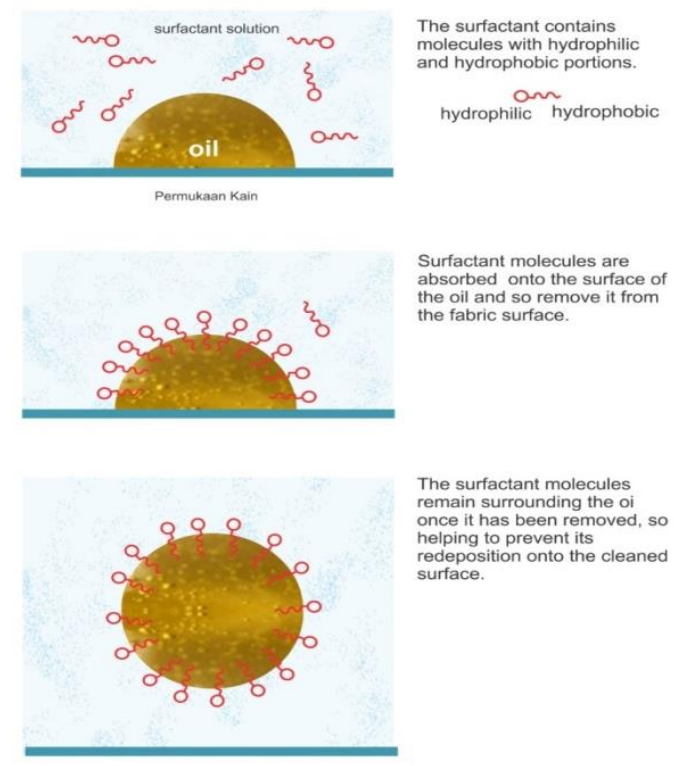
emain surrounding the oi
once it has been removed, so helping to prevent its helping to prevent its
surfacesition onto the cleaned

Fig. 1. TRO's working mechanism in washing process

Mordant.The application of mordanting is intended to provide an intermediary or a bridge for the reaction between the negative charge of the hydroxyl group on cotton fibers with the negative charge of brazillin, tannin or a combination of both. Fig. 2 shows the reaction mechanism that occurs at the mordanting stage. Eliminating this stage from the cotton fiber dyeing will not completely eliminate the color from cotton fabric. The appearance of color in this condition is more triggered by the deposition of dye molecules on the surface and internal pores of the fiber. Appearance of color with these conditions is not beneficial because the dye becomes easily 
wear off. Related to this, all metal compounds that have a positive charge with a valence of more than one can be applied as a mordanting agent. However, the use of metal compounds as mordants must still pay attention to the negative impacts caused, both on living things and the environment. The use of chromium metal compounds positively charged with valences 5 and 6 by many textile industries has been shown to have an adverse effect on living organisms. Carcinogenic effects and non-biodegradable properties are the two main weaknesses of this mordant agent. This is in line with what was reported by [12].

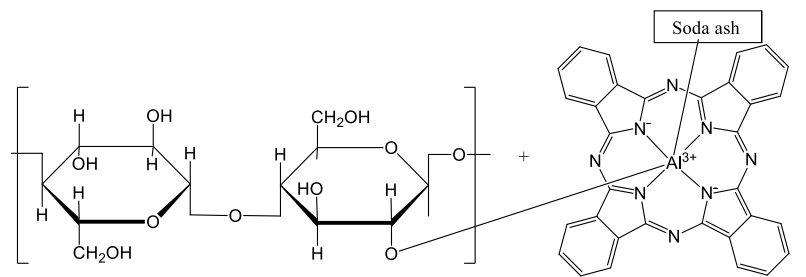

Fig. 2. The reaction mechanism at the mordanting stage
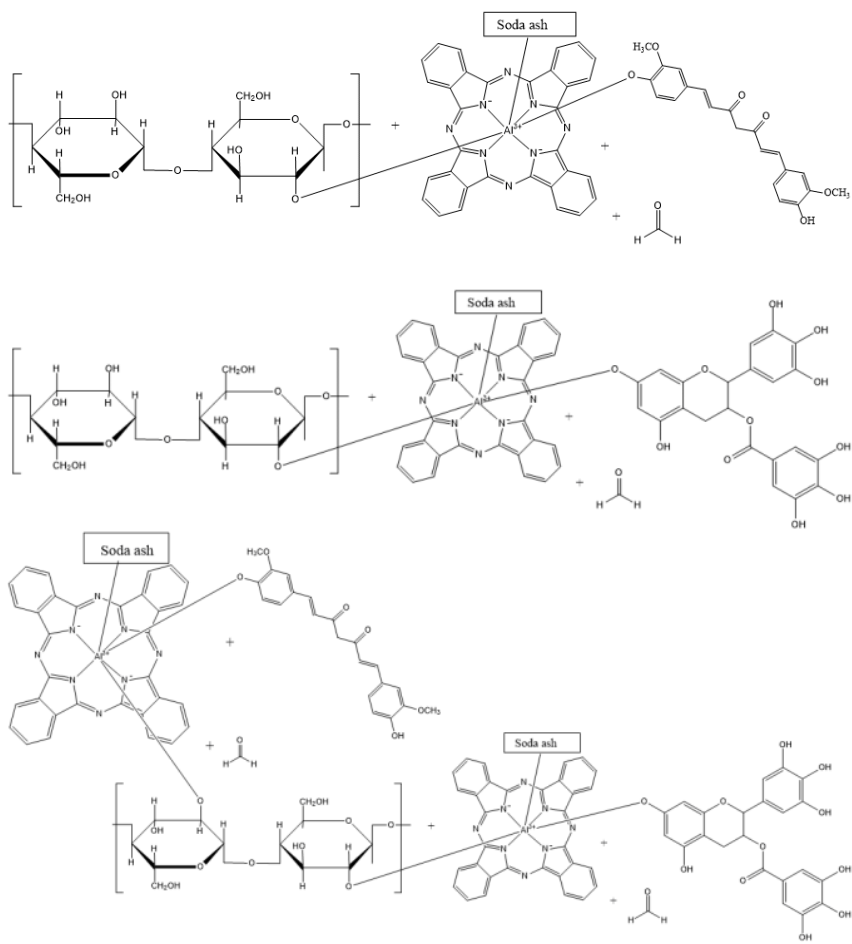

Fig. 3. The reaction mechanism at the dyeing stage

Dyeing. The application of different dyes compositions and fixer types has resulted in the appearance of very different color shades (as in Fig. 3). Dyeing that ends with fixation using iron (II) sulfate tends to produce a dark color, while the application of alum and calcium oxide each produces a bright purple and red color. This color difference is caused by the influence of specific chromophores and auxochromes contained in the molecular structure of each fixer. The type of chromophore and auxochrome will determine the electromagnetic radiation absorption capacity, the maximum wavelength and the type of electronic transition that occurs. Fig. 4 shows the reaction mechanism that occurs in the fixation process.
Fixation is the most important stage after dyeing. The use of fixers can increase the color absorption in the fabric, so it is not easy to fade and is resistant to rubbing [14], lighting, temperature, and washing [15];[16];[17];[18].

TABLE III. RESULF OF DYES COMBINATIONS WITH A DIFFERENT COMPOSITIONS AND FIXER

\begin{tabular}{|c|c|c|}
\hline No & Type of Blending & Result of dyes \\
\hline 1 & BWB/WGL-1a & \\
\hline 2 & BWB/WGL-1b & \\
\hline 3 & BWB/WGL-1c & \\
\hline 4 & BWB/WGL-2a & \\
\hline 5 & BWB/WGL-2b & \\
\hline 6 & BWB/WGL-2c & \\
\hline 7 & BWB/WGL-3a & \\
\hline 8 & BWB/WGL-3b & \\
\hline 9 & BWB/WGL-3c & \\
\hline
\end{tabular}


The BWB, WGL, and combination dyes are prepared using water-solvent extraction and applied with different compositions and fixer types (as shown in Table 3). Color intensity resulting from various extracts can be seen in Table 4.

TABLE IV. THE COLOR INTENSITY WITH A DIFFERENT COMPOSITIONS AND FIXER

\begin{tabular}{lll}
\hline No & Type of Blending & Color Intensity (\%) \\
\hline 1 & BWB/WGL-1a & 76.53 \\
\hline 2 & BWB/WGL-1b & 72.38 \\
\hline 3 & BWB/WGL-1c & 35.60 \\
\hline 4 & BWB/WGL-2a & 87.63 \\
\hline 5 & BWB/WGL-2b & 37.89 \\
\hline 6 & BWB/WGL-2c & 84.01 \\
\hline 7 & BWB/WGL-3a & 78.94 \\
\hline 8 & BWB/WGL-3b & 86.46 \\
\hline 9 & BWB/WGL-3c & 52.59
\end{tabular}

These results indicate that an increase in BWB levels in the mixture has produced a deep red color. This is reinforced by the occurrence of hypsochromic events or shifts in the maximum wavelength of the BWB dye extract in the lower direction. The dominance of the presence of $\mathrm{C}=\mathrm{C}$ and $\mathrm{C}=\mathrm{O}$ chromophores as well as the brazillin typical hydroxide $(\mathrm{OH})$ group as increasing levels of BWB extract has increased the wavelength region where the dye optimally absorbs electromagnetic waves. Fig. 3 shows the reaction mechanism in the cotton fiber dyeing process using a combination of BWB and WGL. The results of the color intensity analysis using DRUV showed a lower color strength of WGL extract than BWB. This condition is caused by the dominance of negatively charged functional groups $\left(\mathrm{HO}-; \mathrm{O}_{2}^{-}\right.$and $\left.\mathrm{CH}_{3} \mathrm{O}^{-}\right)$ in the molecular structure of brazilin compared to tannins, causing more brazilin dyes to bind to the fabric fibers under the same conditions and dyeing composition.

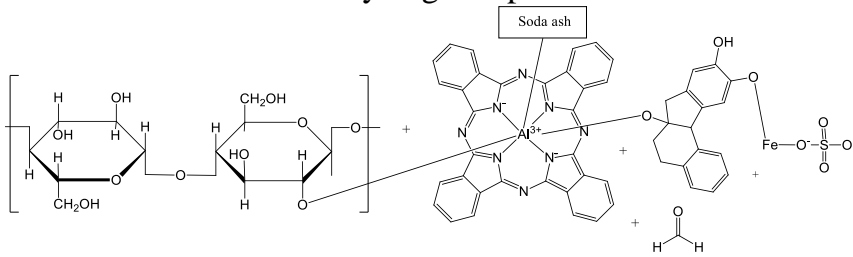

(a)

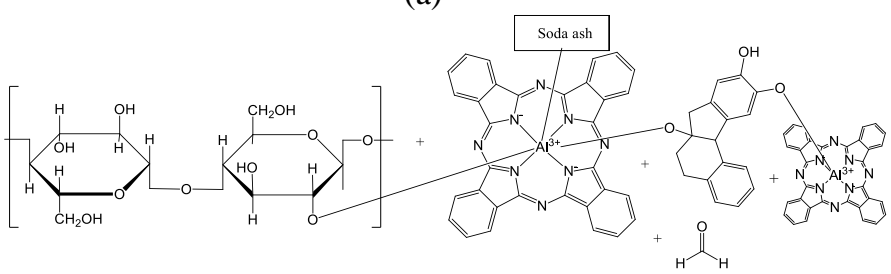

(b)

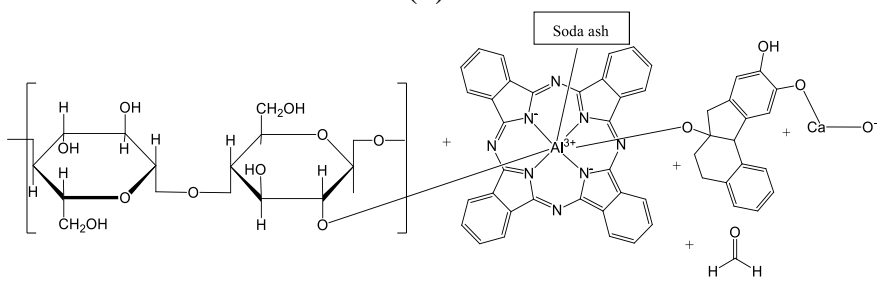

(c)

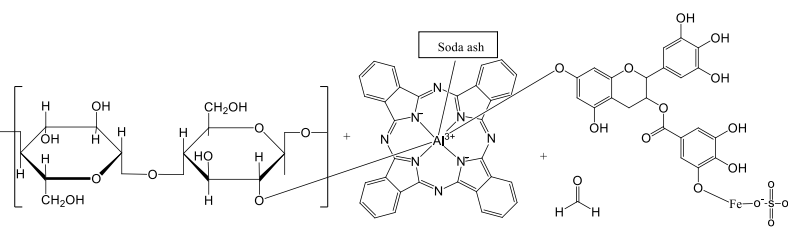

(d)

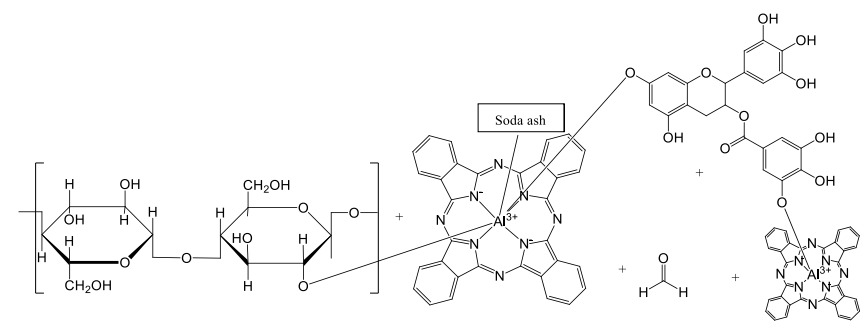

(e)

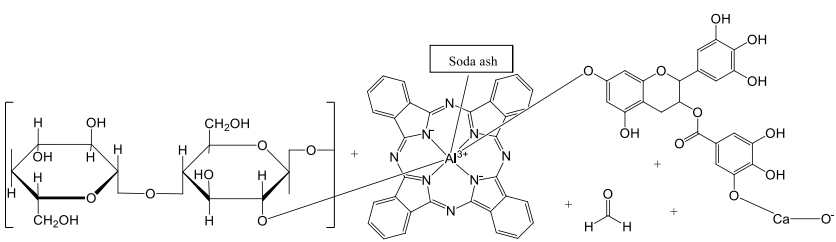

(f)

Fig. 4. The reaction mechanism at the fixation stage:(a) brazilin with iron(II) sulfate(tunjung); (b) brazilin with alum;(c) brazilin with calcium oxide;(d) tanin with iron(II)sulfate(tunjung); (e) tanin withalum; and(f) tanin with calcium oxide (hypotetic)

\section{CONCLUSIONS}

Efforts to find natural ingredients for batik have been made. Consistent characteristics of the extracted material and standard operating conditions are important variables to eliminate the difference in color produced, especially in dyeing using natural dyes such as those produced by a combination of brazilwood bark and water guava leaves. The experimental results show the appearance of three different colors as a result of the fixation process using iron (II) sulfate, alum, and lime compounds, as the composition of the material used increases. Fixation using iron (II) sulfate, alum and lime has caused the appearance of dark red to black, purple, and bright red on cotton fabrics. Color intensity has increased with an increase in the composition of brazillin in the range of $35.60 \%-87.63 \%$.

\section{ACKNOWLEDGMENT}

We would like to thank the Directorate of Research and Community Service, Ministry of Research and TechnologyHigher Education of the Indonesia Republic for providing financial support through Higher Education Superior Applied Research activities.

\section{REFERENCES}

[1] M. Lahlou, "Screening of Natural Products for Drug Discovery," Expert Opinion on Drug Discovery, vol. 2, pp. 697-705, 2007.

[2] N. Kusumawati, Samik, A.G. Santoso, A.Wijiastuti, "Development of Textile Natral Dyeing using Hybrid Dyes from Mango Leaves Turmeric". Atlantiss Press, vol. 171, pp. 50-55.

[3] Lemmens, R.H.M.J, and W.N. Soetjipto, "Dye and Tannin Producing Plants" in Plant resources of Southeast Asia No.3 Wageningan. The Netherlands: Pudoc/Prose, 1992. 
[4] S. Adee, S. Al, I. Bhatti, F.Zsila, "Dyeing of cotton fabric using pomegranate (Punica Granatum) aqueous extract". Asian J.Chem, vol. 21(5), pp. 3493-3499, 2009.

[5] N. Pruthi, G. Chawla, S. Yadav, "Dyeing of silk with barberry bark dye using mordant combination". Natural Product Radiance, vol.7(1), pp. 40-44, 2008.

[6] Vankar, Chemistry of Natural Dyes. Resonance, vol. 5(10), pp. 73-80, 2000 .

[7] R. Siva, "Status of narural dyes and dye yielding plants in India". Current science, vol. 92(7), pp. 916-925, 2007.

[8] D.R. Adawiyah, Indriati, "Color stability of natural pigment from secang woods (Caesalpinia sappan L.”. Proceeding of the Asean Food Conference [Hanoi 8-11 october 200]

[9] D.S. Fardhyanti, R.D. Riski, "Pemungutan Brazilin dari Kayu Secang (Caesalpinia Sappan L) dengan Metode Maserasi dan Aplikasinya untuk Pewarnaan Kain". Jurnal bahan Alam Terbarukan, vol. 4(1), pp. 6-1, 2015.

[10] D. Oktiarni, "Pemanfaatan ekstrak daunj jambu biji (Psidium guajava), daun dewandaru (Eugenia unflora), daun rosella (Hibiscus sabdariffa L.) sebagai pewarna alami tekstil pada kian katun dengan mordan Belimbing Wuluh Universitas Bengkulu, Bengkul, 2012.

[11] M. Astawan, A.L. Kasih, 2008, Khasiat warna-warni makanan. Gramedia: Jakarta, 2008.

[12] N. Kusumawati, A.B. Santoso, M.M. Sianita, S. Muslim, "Extraction, Characterization, and Application of Natural Dyes from The Fresh Mangosteen (Garcinia mangostana L.) Peel”. International Journal on
Advanced Science, Engineering, and Information Technology, 7(3), pp. 878-884, 2017.

[13] F.E. Prado, M. Hilal, S. Chocobar-Ponce, E. Pagano, M. Rosa, C. Prado, "Chapter 6 - Chromium and The Plant: A Dangerous Affair?" Elsevier Inc; New York, NY, USA, (2-16), pp. 149-177, 2016.

[14] L. Ruwana, "Pengaruh zat fiksasi terhadap ketahanan luntur warna pada proses pencelupan kain kapas dengan menggunakan zat warna dari limbah kayu jati (Tectona grandis)". Universitas Negeri Semarang, pp.18, 2008 .

[15] N. Grover, V. Patni, "Extraction and Application of Natural Dye Preparations from the Floral Parts of Woodfordia fruticosa (Linn.) Kurz". Indian Journal of Natural Products and Resources, vol. 2, pp. 403-40, 2011.

[16] A. Devi, B. Sumathy, V. Katyayini, "Trailing Eclipta - A natural green colour for textile". in Natural Dyes Scope and Challenges (ed. M. Daniel), pp. 103-112, 2006

[17] R. Agarwal, B. Schwer, S. Shuman, "Structure-function analysis and genetic interactions of the Luc7 subunit of the Saccharomyces cerevisiae U1 snRNP". The RNA Society, vol. 22(9), pp. 1302-1310, 2016.

[18] A. Shrivastava, E.M. Dedhia, "Extraction and dyeing methods of natural dyes" in M. Daniel (Ed.), Natural Dyes Scope and Challenges Scientific Publication (India) Jodhpu, 2006, pp. 67-7. 